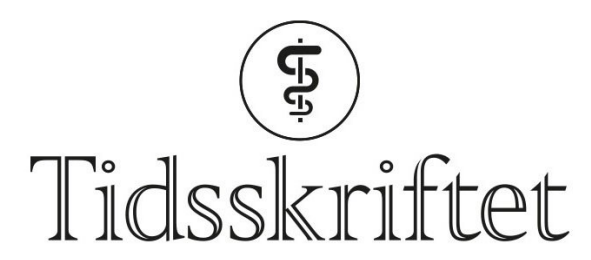

DEN NORSKE LEGEFORENING

\title{
Hypertensjon etter nyredonasjon
}

FRA ANDRE TIDSSKRIFTER

SOFIE PAUS

Tidsskriftet

Personer som donerer en nyre til transplantasjon, har økt risiko for å utvikle hypertensjon.

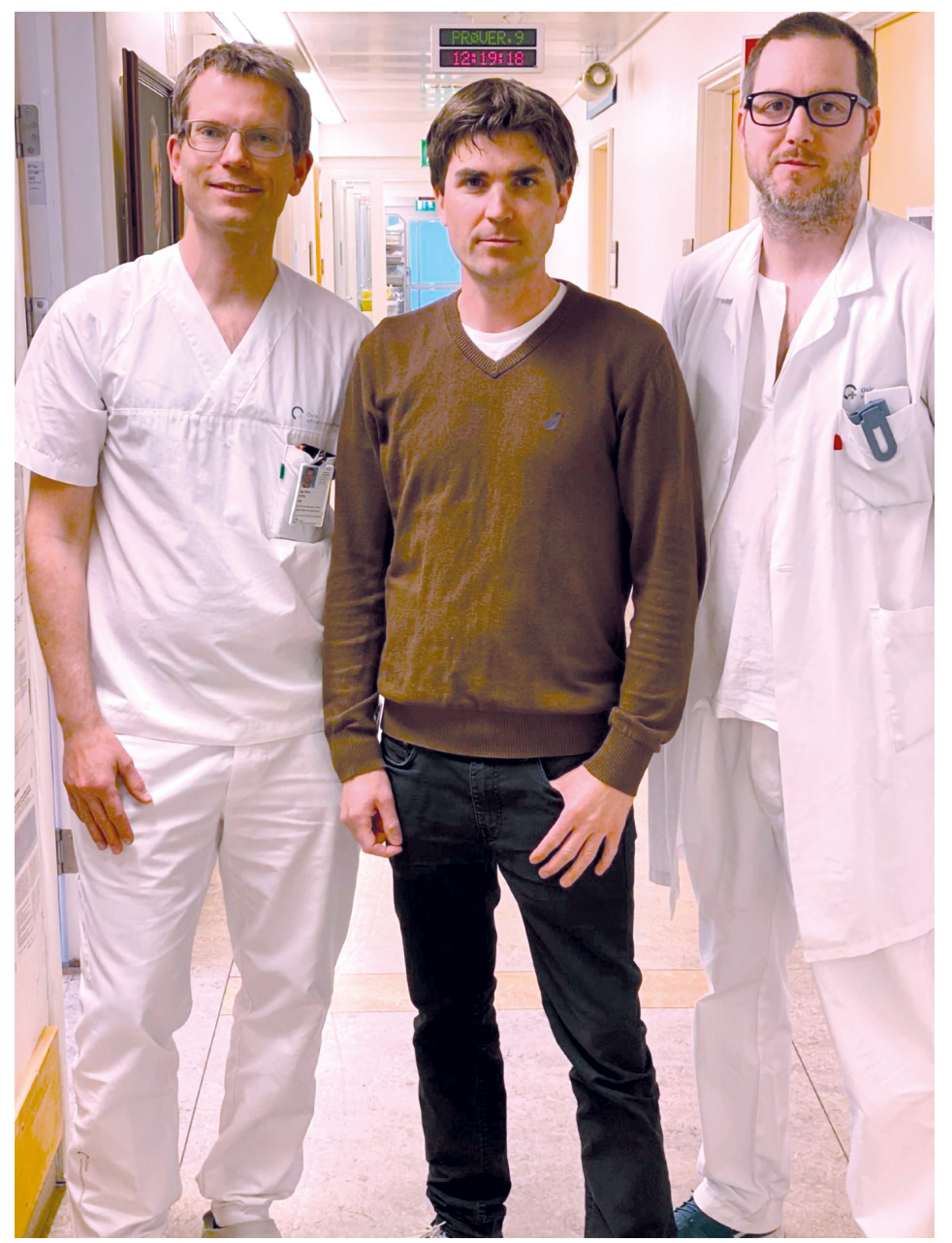

Fra venstre: Medforfatter Dag Olav Dahle, førsteforfatter og stipendiat Anders Haugen og hovedveileder Geir Mjøen. Foto: Sebastian Muller

Å donere en nyre til transplantasjon har tidligere vært ansett som relativt sikkert for donor. En ny norsk studie viser nå at risikoen for høyt blodtrykk øker i årene etter donasjon (1).

Studien er basert på en kohort med 1029 friske, levende nyredonorer som donerte en nyre i perioden 1972-2007. Disse ble sammenliknet med en kontrollgruppe med flere enn 16 
ooo personer fra HUNT-studien i Nord-Trøndelag som var friske i samme tidsperiode som donasjonen fant sted.

Hypertensjon ble definert som blodtrykk over 140/9o mm Hg, bruk av blodtrykksmedisin eller at diagnosen hypertensjon var satt av en lege. I løpet av en gjennomsnittlig oppfølgingstid på 11 år hadde $36 \%$ av donorene og $27 \% \mathrm{i}$ kontrollgruppen utviklet hypertensjon. Justert for blant annet alder og tid sidan donasjon fant man en $25 \% \varnothing k t$ risiko for hypertensjon blant donorer sammenliknet med kontrollpersoner (oddsratio 1,25; 95 \% KI $1,12-1,39)$.

- Disse resultatene har betydning for oppfølgingen av personer som donerer en nyre, og tilsier at det er nødvendig med blodtrykkskontroll i lengre tid etter donasjon, sier Anders Haugen, som er stipendiat og førsteforfatter av studien.

- Donornefrektomi er et kirurgisk inngrep på en frisk person. Det er derfor viktig for kravet om informert samtykke at risikoen ved et slikt inngrep er klarlagt best mulig, sier han.

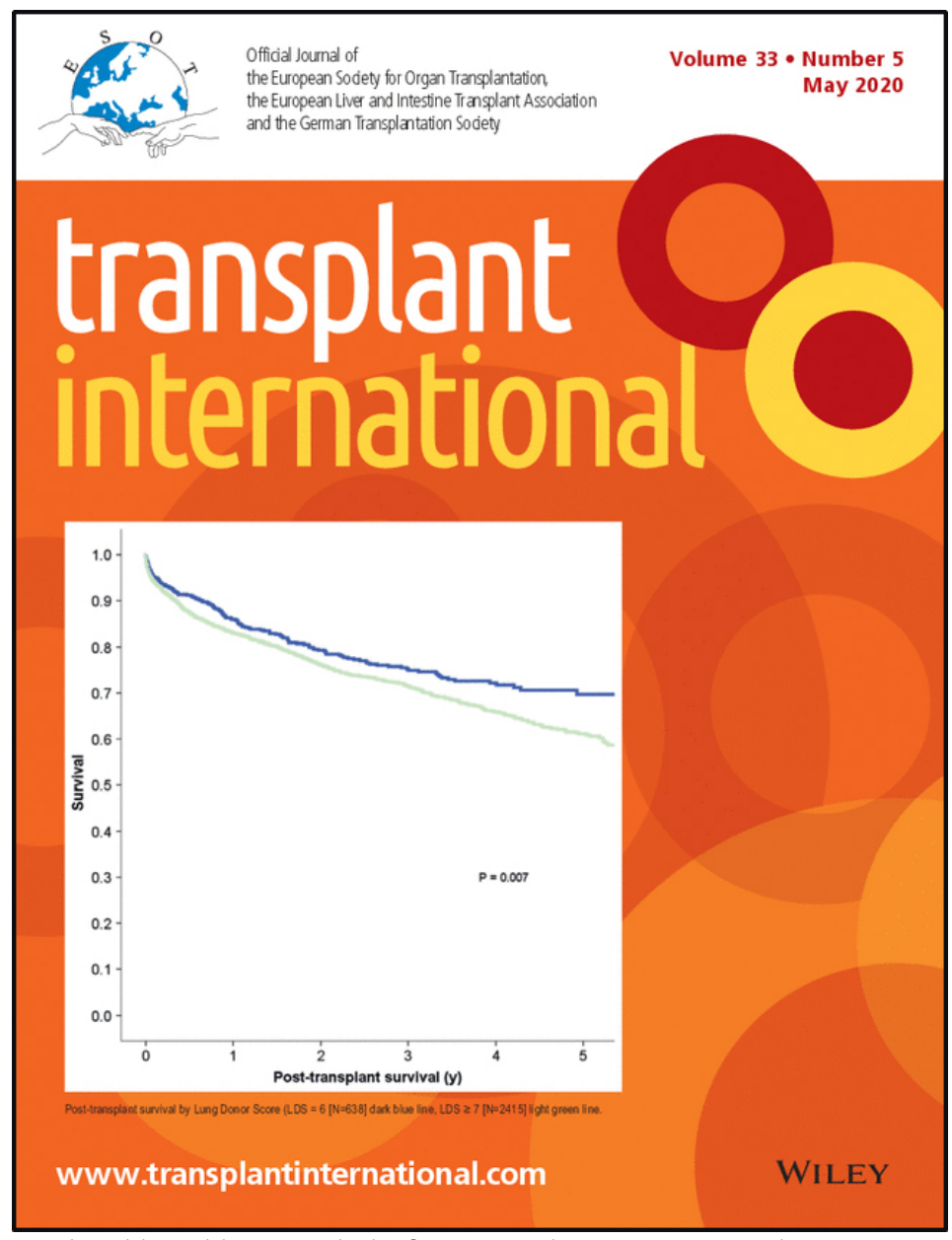

Studien ble publisert i tidsskriftet Transplant International $i$ år.

- En styrke ved studien er at vi bruker en kontrollgruppe som er selektert ut ifra donasjonskriterier på et tidspunkt som tilsvarer tidsrommet for donasjon. Oppfølgingsdata fra donorer ble sammenliknet med oppfølgingsdata fra de samme kontrollpersonene mange år senere. Det å retrospektivt finne en passende kontrollgruppe til donorer er vanskelig. Nyregivere er "ffriskere enn folk flest», de blir screenet for sykdom og må oppfylle flere kriterier for å kvalifisere som givere. Er ikke kontrollgruppen lik nok eller «like friske» som donorer, vil dette skape skjevheter i resultatene. For å unngå falskt positive resultater bør kontrollpersonene ideelt sett være like friske på tidspunktet som donasjonen finner sted, og ikke bare på tidspunktet for selve studien, sier Haugen.

- Dette forskningsprosjektet er en fortsettelse av en tidligere studie som viste $\emptyset \mathrm{kt}$ langtidsmortalitet blant norske levende givere av nyre sammenliknet med kontrollpersoner. Prosjektet har som mål å kartlegge risikofaktorer for sykdom og død 
blant nyredonorer mange år etter donasjon.

Oslo universitetssykehus, Rikshospitalet er nasjonalt senter for nyretransplantasjon, og alle nyretransplantasjoner i landet utføres her, også donornefrektomier. Nyremedisinsk avdeling foretar utredning av potensielle givere og oppfølging etter donasjon. I tillegg følges alle transplanterte pasienter opp på Rikshospitalet den første tiden etter transplantasjonen før lokalsykehusene overtar.

Nyremedisinsk avdeling på Rikshospitalet har ansvaret for et register med data på levende givere fra hele landet. Dette registeret gir gode muligheter for forskning. I tillegg til studier på nyretransplantasjon og levende givere driver avdelingen forskning på bl.a. diabetes, pankreastransplantasjon og immundempende behandling.

LITTERATUR:

1. Haugen AJ, Hallan S, Langberg NE et al. Increased long-term risk for hypertension in kidney donors a retrospective cohort study. Transpl Int 2020;33: 536-43. [PubMed][CrossRef]

Publisert: 8. juni 2020. Tidsskr Nor Legeforen. DOI: 10.4045/tidsskr.20.0399

(C) Tidsskrift for Den norske legeforening 2020. Lastet ned fra tidsskriftet.no 